Fols View/Frint Document Cover Sheet tok

This document was retrieved from the Boeing ISEARCH System.

Accession \#: D196069801

Document \#: SD-WM-TP-249

Title/Desc:

TANK 241U111 TANK CHARACTERIZATION PLAN 


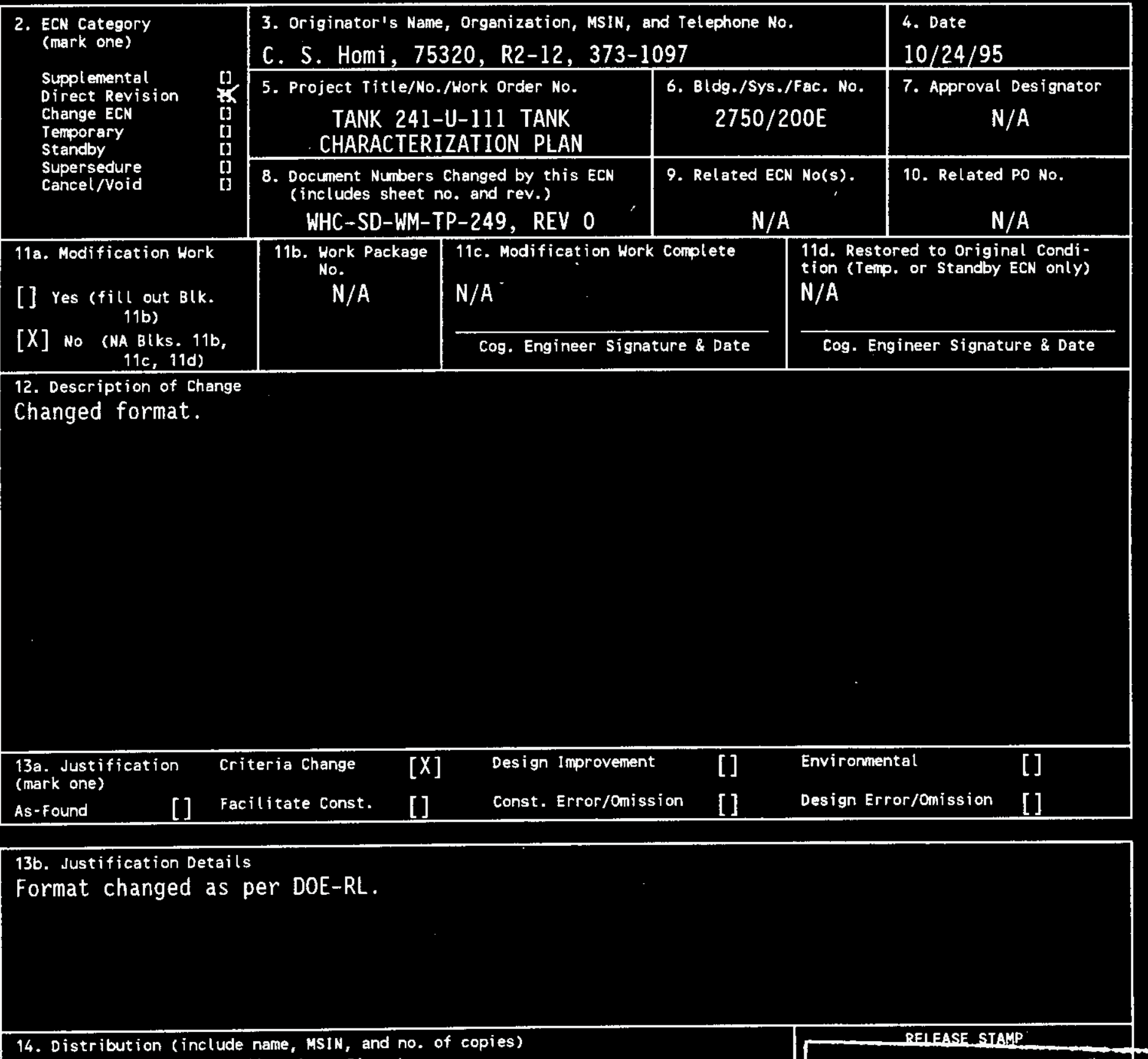

13b. Justification Details

Format changed as per DOE-RL.

14. Distribution (include name, MSIN, and no. of copies)

See attached Distribution Sheet.

RELEASE STAMP 


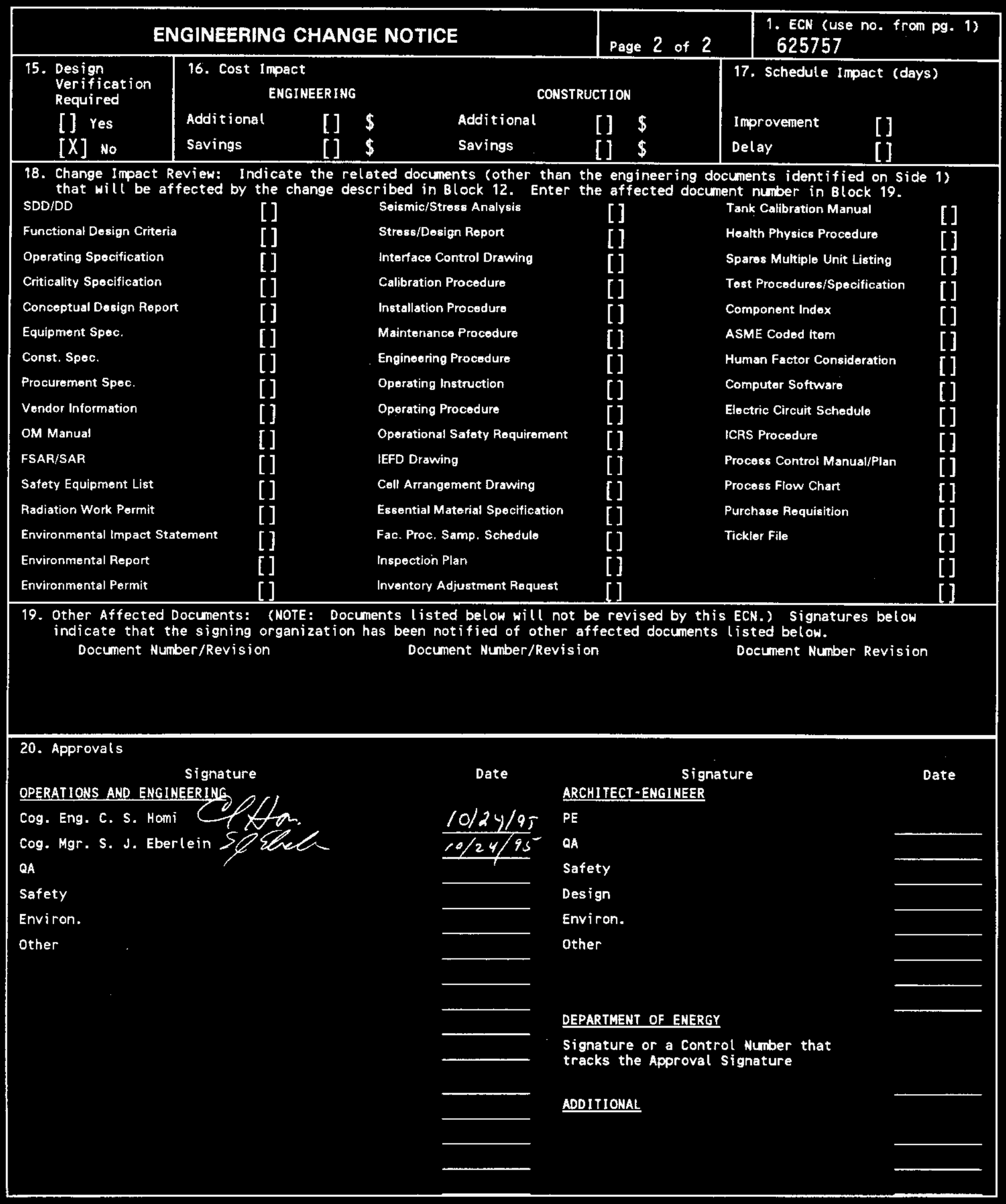




\section{RELEASE AUTHORIZATION}

Document Number: WHC-SD-WM-TP-249, REV 1

Document Title: Tank 241-U-111 Tank Characterization Plan

Release Date: $\quad 10 / 25 / 95$

This document was reviewed following the
procedures described in WHC-CM-3-4 and is:

APPROVED FOR PUBLIC RELEASE

WHC Information Release Administration Specialist:
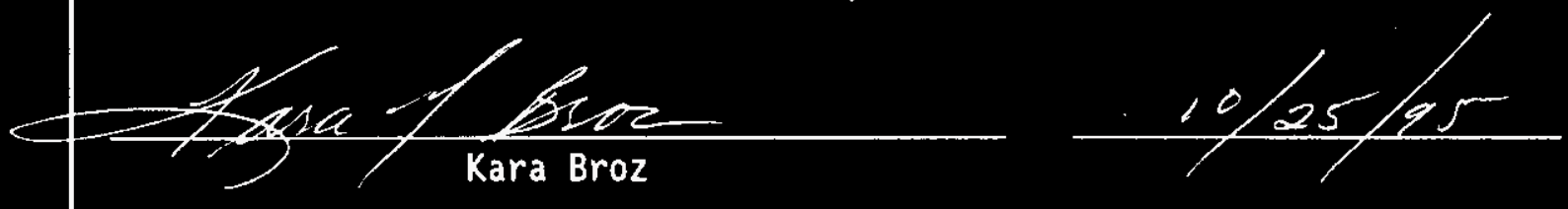

TRADEMARK DISCLAIMER. Reference here in to any specific commercial product, process, or service by trade name, trademark, manufacturer, or otherwise, does not necessarily constitute or imply its endorsement, recommendation, or favoring by the United States Government or any agency thereof or its contractors or subcontractors.

This report has been reproduced from the best available copy. Available in paper copy. Printed in the United States of America. To obtain copies of this report, contact:

West inghouse Hanford Company - Document Control Services

P.0. Box 1970, Mailstop H6-08, Richland, WA 99352

Telephone: (509) 372-2420; Fax: (509) 376-4989 


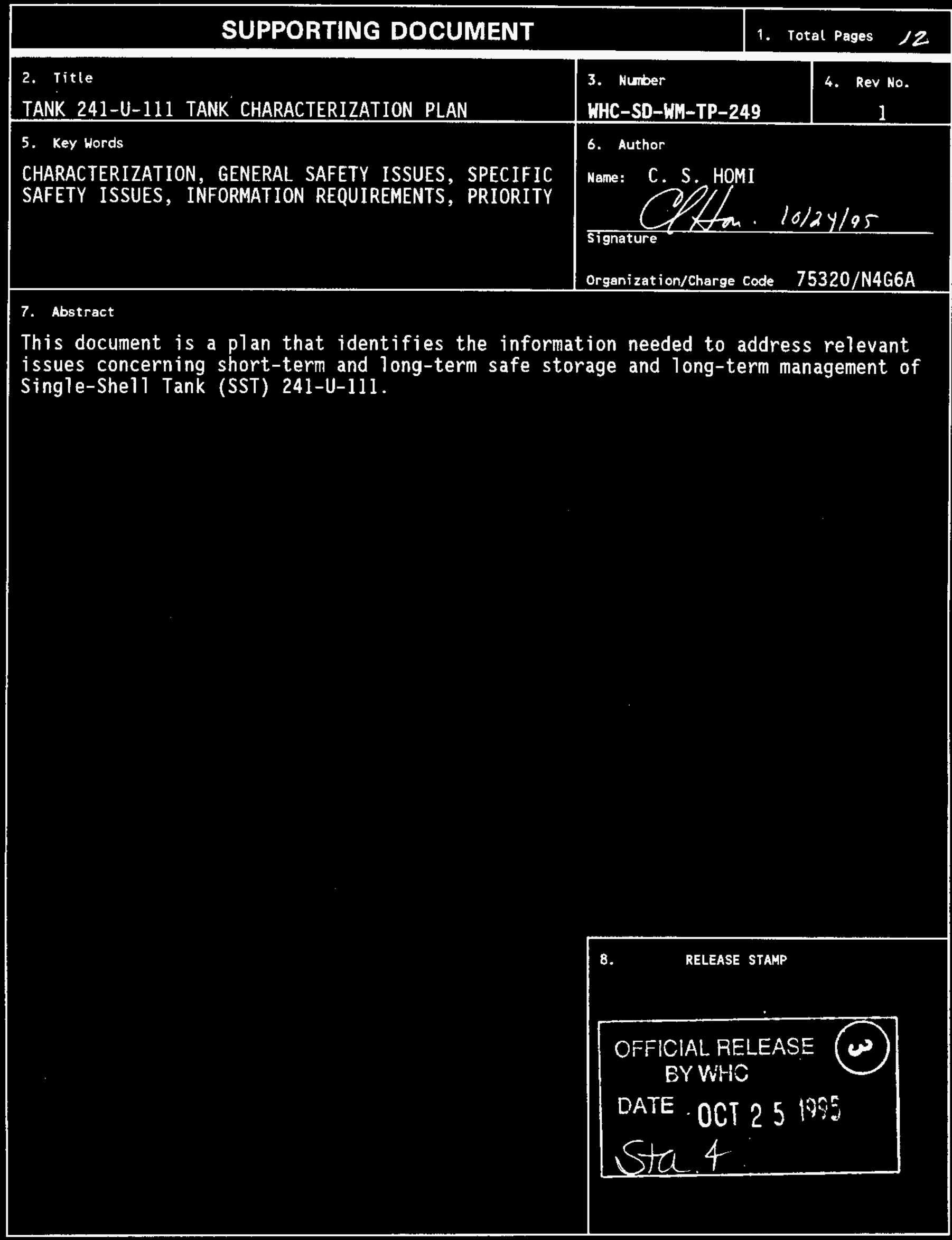




\begin{tabular}{|l|l|l|}
\hline RECORD OF REVISION & $\begin{array}{l}\text { (1) Document Kumber } \\
\text { WHC-SD-WM-TP-249 }\end{array}$ & Page 1 \\
\hline
\end{tabular}

\begin{tabular}{|c|c|c|c|}
\hline \multicolumn{4}{|c|}{$\begin{array}{l}\text { (2) Title } \\
\text { TANK 241-U-111 TANK CHARACTERIZATION PLAN } \\
\text { CHANGE CONTROL RECORD }\end{array}$} \\
\hline \multirow{2}{*}{ Revision } & \multirow{2}{*}{ (4) Description of Change - Replace, Add, and Delete Pages } & \multicolumn{2}{|c|}{ Authorized for Release } \\
\hline & & (5) Cog. Engr. & (6) Cog. Mgr. Date \\
\hline 0 & $\begin{array}{l}\text { (7) WHC-SD-WM-TP-249 REV. 0, EDT 610008, } \\
\text { February } 1,1995\end{array}$ & & \\
\hline $1 \mathrm{RS}$ & Changed format ECN 625757 & 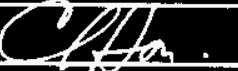 & DShe $10 / 24 / 93$ \\
\hline & & & \\
\hline & & & \\
\hline & & & \\
\hline & & & \\
\hline & & & \\
\hline & & & \\
\hline & & & \\
\hline & & & \\
\hline & & & \\
\hline & & & \\
\hline & & & \\
\hline & & & \\
\hline & & & \\
\hline & & & \\
\hline & & & \\
\hline & & & \\
\hline & & & \\
\hline & & & \\
\hline & & & \\
\hline & & & \\
\hline & & & \\
\hline & & & \\
\hline & & & \\
\hline & & & \\
\hline & & & \\
\hline & & & \\
\hline & & & \\
\hline
\end{tabular}




\title{
Tank 241-U-111 \\ Tank Characterization Plan
}

\author{
C. S. Homi
}

Westinghouse Hanford Company

Date Published

October 1995

Prepared for the U.S. Department of Energy

Office of Environmental Restoration and

Waste Management

(2) Westinghouse $\begin{aligned} & \text { P.O Box } 1970 \\ & \text { Hanford Company Richland, Washingion }\end{aligned}$

Menagement end Operations Contractor for the

U.S. Deparment of Energy under Contrat: DE.ACOE.87FL 10930

- Approved for Public Release 


\section{WHC-SD-WM-TP-249, REV 1}

\section{TABLE OF CONTENTS}

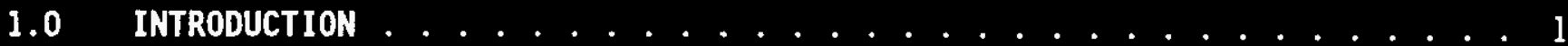

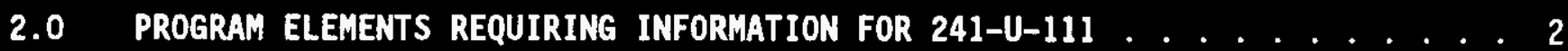

2.1 GENERAL SAFETY ISSUES ................... 2

2.2 SPECIFIC SAFETY ISSUES $\ldots \ldots \ldots \ldots \ldots$

2.2.1 Ferrocyanide ........................ 2

2.2 .2 Organic . . . . . . . . . . . . . . . . . . . 2

2.2.3 High Heat . . . . . . .................... 2

2.2.4 Flammable Gas . . . . . . . . . . . . . . . . . . . 2

2.2.5 Vapor ......................... 2

2.2.6 Criticality . . . . . . . . . . . . . . . . . . . 3

2.2.7 Screening Approach Evaluation . . . . . . . . . . . . . . . . . 3

2.3 CONTINUTNG OPERATIONS . . . . . . . . . . . . . . 3

2.2.1 Compatibility/Stabilization . . . . . . . . . . . . . 3

2.2.2 Evaporator .................... 3

2.4 DOUBLE-SHELL TANK WASTE ANALYSIS PLAN . . . . . . . . . . 3

2.5 DISPOSAL . . . . . . . . . . . . . . . . . . . . 3

2.5.1 Retrieval . . . . . . . . . . . . . . . . . . . 3

2.5.2 Pretreatment/Vitrification ................. 3

2.6 HISTORICAL MODEL EVALUATION ............... 3

3.0 HOW INFORHATION WILL BE OBTAINED . . . . . . . . . . . . 4

4.0 PRIORITY OF INFORMATION REQUIREMENTS . . . . . . . . . . . . 5

5.0 WHEN INFORMATION IS NEEDED ............... 5

6.0 REFERENCES ........................ 6

\section{LIST OF TABLES}

Table 4-1: Integrated DQO Requirements ............. 5 
WHC-SD-WH-TP-249, REV 1

\section{LIST OF ABBREVIATIONS}

$\begin{array}{ll}\text { DQO } & \text { Data Quality Objective } \\ \text { DSSF } & \text { Double She11 Slurry Feed } \\ \text { HTCE } & \text { Historical Tank Content Estimate } \\ \text { SST } & \text { Single-She11 Tank } \\ \text { SUMMA } & \text { Trademark of Molectrics, Inc. } \\ \text { TCP } & \text { Tank Characterization Plan } \\ \text { TOC } & \text { Total Organic Carbon } \\ \text { U-111 } & \text { Tank 241-U-111 } \\ \text { USQ } & \text { Unreviewed Safety Question } \\ \text { WHC } & \text { Westinghouse Hanford Company }\end{array}$




\subsection{INTRODUCTION}

This Tank Characterization Plan (TCP) identifies the information needed to address relevant issues concerning short-term and long-term safe storage and long-term management of Single-She11 Tank 241-U-111 (U-111). It should be understood that the various needs and issues surrounding tank $U-111$ are evolving as new information about the tank is uncovered. As a result of this progression, this Tank Characterization Plan addresses only the issues that, to this date, have been identified. It is expected that deviations from this plan may occur as additional issues or needs arise which impact the management of SST U-111. As necessary, this Tank Characterization Plan will be revised to reflect those changes or deviations.

Tank U-111 was constructed between 1943 and 1944 and was put into service in April 1947. Initially tank $U-111$ received $1 C$ waste (created by the bismuth phosphate $\left(\mathrm{BiPO}_{4}\right)$ process), from the second quarter of 1947 until the third quarter of 1968 . Tank U-111 received and/or contained REDOX waste from the first quarter of 1954 until the second quarter of 1975. From the third quarter of 1974 unti1 the second quarter of 1975, tank U-111 received wastewater. During the third quarter of 1975 , U-111 received Battelle Laboratory, $\mathrm{N}$ reactor, decontamination and laboratory wastes. from the fourth quarter of 1975 until the second quarter of 1976, the tank received 242-S Evaporator bottoms and recycle wastes. Additionally, U-111 received concentrated evaporator feed during the third quarter of 1976 . U-111 contained evaporator feed, residual evaporator 1 iquor or Hanford defense Residual Liquor wastes until the second quarter of 1978 . From the second quarter of 1978 until the third quarter of 1980, tank U-111 contained partial neutralized feed or complexed waste. Also, during the third quarter of 1979, U-111 received a $\mathrm{HNO}_{3} / \mathrm{KMnO}_{4}$ solution. Presently, tank $U-111$ waste is classified as Double-Shell Slurry feed. This tank currently contains waste with a total waste volume of $1,245.5 \mathrm{~kL}$ (329 kgal), which is equivalent to 292.3 centimeters (115.1 inches) of waste as measured from the baseline of the tank. The waste is comprised of $98.4 \mathrm{~kL}$ (26 kgal) of sludge; $730.6 \mathrm{~kL}$ (193 kgal) of saltslurry and $416.4 \mathrm{~kL}$ (110 kgal) of saltcake with $374.8 \mathrm{~kL}$ (99 kgal) pumpable liquid remaining (Brevick 1994b).

The tank is sound and was removed from service in 1980. Tank $U-111$ is passively ventilated and was partially isolated in December 1982. The 1ast photo was taken on June 23, 1988. The last solids volume update was obtained on April 28, 1988 (Hanlon 1995). The 1988 photographic montage indicates a waste surface that has a mixture of different components from which all moisture has evaporated and; also, it appears that the tank contents are completely dried out (Brevick 1994b). The surface components appear to be a mixture of white and brown compounds.

An analys is of tank waste was conducted on samples obtained on September 23, 1980. The waste samples from U-111 were obtained from two different tank locations; the surface and one foot above a sludge layer. The surface sample was dark green with suspended particles, while the lower sample was a coarse slurry. Both samples contained nitrates, carbonates, phosphates, hydroxides and aluminum compounds. Also, the surface sample contained nitrites. Additionally, TOC was determined to equal $0.52 \%$. Waste was added to tank U-111 after earlier sampling efforts and; therefore, earlier sample analyses are not representative of tank contents.

This tank is on the Organics Watch list. The tank has an Unreviewed Safety Question (USQ) because of the potential consequences of a radiological release resulting from an ignition and/or volatile reaction of the organic constituents. Near-term sampling and analysis activities are focused on either verification of the watchlist tank status, identification of any new safety issues, changing the Watch List status, or resolving the USQ. Should any safety issues be identified additional analysis will occur consistent with the identified issue. 


\section{WHC-SD-WM-TP-249, REV 1}

In addition to the resolution of the safety issues, it is intended that all tank waste will be subject to pretreatment and retrieval to prepare for final storage or disposal. Presently, these long-range plans have yet to be fully identified and are, therefore, not included in this document.

\subsection{PROGRAM ELEMENTS REQUIRING INFORMATION FOR TANK 241-U-111}

This section identifies the various program elements, and identifies which of these programs require characterization data from tank $U-111$.

\subsection{GENERAL SAFETY ISSUES}

The Tank Safety Screening Data Quality Objective (Dukelow et al. 1995) describes the sampling and analytical requirements that are used to screen waste tanks for unidentified safety issues. The primary analytical requirements for the safety screening of a tank are density, energetics, total alpha activity, and flammable gas concentration. Moisture determination is also needed to make correction to the total fuel dry basis criteria.

\subsection{SPECIFIC SAFETY ISSUES}

\subsubsection{Ferrocyanide}

This tank is not on the Ferrocyanide Watch List and; therefore, no information needs are currently identified for this program element.

\subsubsection{Organic}

Tank U-111 is on the Organics Watch List. Sampling and analys is requirements must be performed as per Data Quality Objective to Support Resolution of the Organic Complexant Safety Issue (Turner et al. 1995). The analyses employed will determine the $T O C$, presence of a free organic liquid phase, moisture content and tank temperature.

\subsubsection{High Heat}

This tank is not on the High Heat Watch List and; therefore, no information needs are currently identified for this program element.

\subsubsection{Flanmable Gas}

This tank is not on the Flammable Gas Watch List and; therefore, no information needs are currently identified for this program element.

\subsubsection{Vapor}

The tanks currently scheduled to be vapor sampled may be classified into four categories: (1) those tanks which are to be rotary mode core sampled (as a consequence of the rotary sampling system); (2) tanks on the Organic or Ferrocyanide Watch Lists; (3) tanks in C farm; and (4) tank BX-104, due to vapor exposure. Since tank U-111 is categorized in one of the above four groups, information needs must satisfy Data Quality objectives for Generic In-Tank Health and Safety Vapor Issue Resolution (Osborne et al. 1995) and Rotary Sampling Core Vapor Sampling Data Quality Objective (Price 1994). Characterization of the tank headspace is needed to: 1) identify those 
tanks which can be sampled safely with intrusive equipment without risk of gas ignition; 2) identify and estimate concentrations of toxicologically significant compounds present in the tank headspace to establish worker safety precautions; and 3 ) support the startup and operation of the portable exhauster used during rotary-mode core sampling.

\subsubsection{Criticality}

No information separate from that for the general safety issue of tank U-111 are currently identified for this program element. However, if the general safety screening of tank $U-111$ identifies a potential criticality concern, analyses for fissile materials and neutron absorbers and poisons will be performed as identified in the safety screening data quality objective.

\subsubsection{Screening Approach Evaluation}

The safety screening approach is currently under review. Information is required from key tanks to determine if a revised approach to screening may be adopted, as proposed in Meacham 1995.

\subsection{CONTINUING OPERATIONS}

\subsubsection{Compatibility/Stabilization}

No information needs are currently identified for this program element.

\subsubsection{Evaporator}

No information needs are currently identified for this program element.

\subsection{DOUBLE-SHELL TANK WASTE ANALYSIS PLAN}

This section does not apply because tank $U-111$ is a single shell tank.

\subsection{DISPOSAL}

\subsubsection{Retrieval}

Current retrieval needs (Bloom 1995) do not call for test samples to be taken from tank U-111.

\subsubsection{Pretreatment/Vitrification}

Tank $U-111$ has not been identified as a bounding tank for pretreatment/disposal process development (Kupfer 1995).

\subsection{HISTORICAL MODEL EVALUATION}

Bounding tanks and data requirements for historical model evaluations are found in DQO Historical Model Evaluation Data Requirements (Simpson 1995). Tank U-111 has been identified as a non-primary bounding tank for the S1 saltcake and S2 saltslurry waste types. 


\subsection{HOW INFORMATION WILL BE OBTAINED}

The safety screening $D Q 0$ requires that a vertical profile of the tank waste be obtained from at least two widely spaced risers. This vertical profile may be obtained using core, auger (for shallow tanks), or grab samples. Several sampling events of tank U-111 are scheduled: one vapor sampling event and a rotary core sampling event. No other sampling is scheduled through fiscal year 1996 (Stanton 1995). The rotary mode sampling type has been chosen over other sampling modes due to both the depth of the tank (making auger sampling inadequate) and the fact that the surface of tank U-111 is comprised of saltcake (which is not conducive to good push mode core sampling recovery). Prior to rotary sampling it is necessary to vapor sample the tank as per requirements of (Price 1994). The vapor sampling activity was completed in March of 1995.

The best current estimate of the water content in tank U-111 solids, as determined from the process records, is $45.0 \%$; based on the HTCE (Brevick et al). Estimated (Toth et al 1995) water content in tank $U-111$ saltcake and sludge is $37.7 \%$ and $29.8 \%$ respectively (generated from a model based on sample data from similar tanks). Moisture data will be used to correct the fuel waste dry basis and, if required, to resolve any safety issues. The TOC contained within the saltcake and sludge is estimated (Toth et a1 1995) to be $0.6 \%$ and $0.3 \%$ (wet basis) respectively, which is significantly lower than the level of concern. Ideally five core samples will be requested for this tank and this should meet the requirements for the above parameters.

The best current information indicates that 5 risers are available for sampling of tank U-111, $12^{\prime \prime}(30.5 \mathrm{~cm})$ risers R3, R6, R7 and $4^{\prime \prime}(10.2 \mathrm{~cm})$ risers R10 and R19. It is recommended that these risers be chosen because, they are risers that are separated radially to the maximum extent possible and; therefore, will provide a larger amount of data about the vertical and horizontal waste layers within the tank. Initial information will be taken from these 5 risers and assessed to determine if more samples are required. One additional riser is available but, equipment will have to be removed from the riser to utilize it for sampling. Alternate sampling methods, installation of a riser or removal of equipment from risers presently considered unavailable, are possible future options. 
HHC-SD-WM-TP-249, REV 1

\subsection{PRIORITY OF INFORMATION REQUIREMENTS}

Characterization of flammable and toxic vapors is a high priority for this tank. Vapor sampling was completed in March 1995 (Stanton 1995). Rotary core sampling is scheduled for early FY 1996 (Stanton 1995).

Table 4-1: Integrated DQO Requirements

\begin{tabular}{|l|l|l|l|}
\hline $\begin{array}{l}\text { Sampl ing } \\
\text { Event }\end{array}$ & \multicolumn{1}{|c|}{ Appl Icable DQO } & Sampling Requirements & Analytical Requirements \\
\hline $\begin{array}{l}\text { Vapor } \\
\text { Sampling }\end{array}$ & $\begin{array}{l}\text {-Health \& Safety Vapor } \\
\text { Issue Resolut ion DQO } \\
\text {-Rotary Sampl ing Core } \\
\text { Vapor Sampling DQO }\end{array}$ & $\begin{array}{l}\text { 3 SUMMAQ canisters } \\
12 \text { Triple Sorbent Traps } \\
\text { 6 Sorbent Trap Systems }\end{array}$ & $\begin{array}{l}\text { Gas Flammability } \\
\text { Gas Toxicity } \\
\text {-Organic Vapors } \\
\text {-Permanent Gases }\end{array}$ \\
\hline $\begin{array}{l}\text { Rotary } \\
\text { Core } \\
\text { Sampling }\end{array}$ & $\begin{array}{l}\text {-Safety Screening DQ0 } \\
\text {-Organic Compexant DQO } \\
\text {-Historical Model DQO }\end{array}$ & $\begin{array}{l}\text { Core samples from 5 } \\
\text { risers separated } \\
\text { radially to the maximum } \\
\text { extent possible }\end{array}$ & $\begin{array}{l}\text { Energetics, Moisture, } \\
\text { Total Alpha, TOC, SpG } \\
\text { (Density) }\end{array}$ \\
\hline
\end{tabular}

\subsection{WHEN INFORMATION IS NEEDED}

Data are required for Tank U-111 during FY 1996 for safety screening and to prepare a Tank Characterization Report. 


\section{WHC-SD-WM-TP-249, REV 1}

\subsection{REFERENCES}

Bloom, G. R., and Q. H. Nguyen, 1995, Characterization Data Needs for Development, Design, and Operation of Retrieval Equipment Developed Through the Data Quality Objective Process, WHC-SD-WM-DQO-008, Rev. 0, Westinghouse Hanford Company, Richland, Washington.

Brevick, C. H., 1994a, Historical Tank Content Estimate for the Northeast Quadrant of the Hanford 200 East Areas, WHC-SD-WM-ER-349, Rev. OA, ICF Kaiser Hanford Company, Richland, Washington.

Brevick, C. H., 1994b, Supporting Document for the Historical Tank Content Estimate for BX Tank Farm, WHC-SD-WM-ER-311, Rev. O, ICF Kaiser Hanford Company, Richland, Washington.

Brown, T. M., S. J. Eberlein, D. A. Dodd, T. J. Kunthara, B. C. Simpson, and N. W. Kirch, Tank Waste Characterization Plan and Basis, 1995, WHC-SD-WM-TA-164, Rev 0, Westinghouse Hanford Company, Richland, Washington.

Dukelow, G. T., J. W. Hunt, H. Babad, and J. E. Meacham, 1995, Tank Safety Screening Data Quality Objective, WHC-SD-WM-SP-004, Rev 2, Westinghouse Hanford Company, Richland, Washington.

Hanlon, B.M., 1995, Waste Tank Summary for Month Ending May, 1995, WHC-EP-0182-82, West inghouse Hanford Company, Richland, Washington.

Homi, C. S., and S. J. Eberlein, 1995, Fiscal Year 1996 Tank Waste Remediation System Tank Waste Analysis Plan, WHC-SD-WM-PLN-101, Rev 0, Westinghouse Hanford Company, Richland, Washington

Kupfer, M. J., W. W. Schultz, and J. T. Slankas, 1995, Strategy for Sampling Hanford Site Tank Wastes for Development of Disposal Technology, WHC-SD-WM-TA-154, Rev. 1, Westinghouse Hanford Company, Richland, Washington.

McDuffie, N. G., 1995, Flammable Gas Tank Safety Program: Data Requirements for Core Sample Analysis Developed Through the Data Quality Objectives (DQO) Process, WHC-SDWM-DQ0-004, Rev. 1, Westinghouse Hanford Company, Richland, Washington

Meacham, J. E., R. J. Cash, B. A. Pulsipher, and G. Chen, 1995, Data Requirements for the Ferrocyanide Safety Issue Developed through the Data Quality Objectives Process, WHC-SD-WM-DQ0-007, Rev. 1, Westinghouse Hanford Company, Richland, Washington.

Osborne, J.W., J.L. Huckaby, E.R. Hewitt, C.M. Anderson, D.D. Mahlum, B.A. Pulsipher, and J.Y. Young, 1995, Data Quality Objectives for Generic In-Tank Health and Safety Vapor Issue Resolution, WHC-SD-WM-DQ0-002, Rev. 1, Westinghouse Hanford Company, Richland, Washington.

Price, D. N., 1994, Rotary Core Vapor Sampling Data Quality Objective, WHC-SD-WM-SP-003, Rev. 0, Westinghouse Hanford Company, Richland, Washington.

Simpson, B. C., and D. J. McCain, 1995, Historical Model Evaluation Data Requirements, WHC-SD-WM-DQO-018, Rev. 0, Westinghouse Hanford Company, Richland, Washington.

Stanton, G. A., 1995, Baseline Sampling Schedule, Revision 4.4, (internal memo 74320-95-04, to distribution, March 24), Westinghouse Hanford Company, Richland, Washington. 


\section{WHC-SD-WH-TP-249, REV 1}

Toth, J. J., P. G. Heasler, M. E. Lerchen, J. G. Hill, and P. D. Whitney, 1995, Analysis of Organic Carbon and Moisture in Hanford Single-Shell Tank Waste, PNL10360, Pacific Northwest Laboratory, Richland, Washington.

Turner, D. A., H. Babad, L. L. Buckley, and J. E. Meacham, 1995, Data Quality Objective to Support Resolution of the Organic Complexant Safety Issue, WHC-SD-WM-DQ0-006, Rev. 2, West inghouse Hanford Company, Richland, Washington. 